\title{
Особенности применения регуляторов роста в технологии производства саженцев яблони в условиях предгорной зоны садоводства
}

Смирнов Р.В.

ФГБОУ ВО «Кубанский государственный аграрный университет имени И.Т. Трубилина», Краснодар, Россия e-mail: smirnov_roman88@mail.ru

Ключевые слова: яблоня, сорто-подвойные комбинации, регуляторы роста

Мотивация и цель: На данный момент рынок перенасыщен некачественным материалом. Некомпетентное отношение к процессу приводит к существенным материальным потерям во всей отрасли. Оптимизация производственных процессов в питомнике является весьма значимой на данный момент. Цель исследований - разработать инновационные элементы технологии производства высококачественного посадочного материала яблони в условиях предгорной зоны садоводства.

Meтоды u алгоритмы: Химические обработки проводились в конце июня при достижении растениями высоты 60 см [1]. Обработку препаратом «Эплин» проводили раствором препарата согласно рекомендации производителя 0,6 г/л. Обработку препаратом Д-6 проводили в двух различных концентрациях раствора 0,006 и 0,004 мг/л. Применение препаратов проводили в вечернее время обрабатывая участок центрального побега от высоты 40 см от земли до точки роста $[2,3]$. Определение влияния регуляторов роста Эпллин и Д-6 проводили методом учета биометрических показателей.

Pезультаmы: Применение регуляторов роста повысило количество боковых побегов сорта Чемпион на всех подвойных комбинациях. Так на подвое М 9 наибольшее количество разветвлений отмечалось в опыте с применением препарата Д-6 в концентрации 0,004 г/л, что выше контроля на 53\%. На подвоях ММ 106 и ПБ 9 этот же препарат, но уже в большей концентрации $(0,006$ г/л) также оказал воздействие на образование боковых ответвлений в сравнении с контролем на 44,4 и 75\% соответственно. Стоит также отметить влияние препарата Д-6 на прирост диаметра штамба в комбинации Чемпион/ ПБ 9. В комбинации Ренет Симиренко/ М 9 применение препарата Д-6 в концентрации 0,006 показатель превышал контроль на 36,8\%. В комбинации Ренет Симиренко/ ПБ 9 обе концентрации этого препарата дали одинаковые результаты по сравнению с контролем. Лучший результат по количеству разветвлений был получен при обработке регулятором роста Эплин сорт подвойной комбинации Голд Раш/ M 9 и Голд Раш/ ПБ 9 с применением регулятора роста Д-6 в концентрации 0,004 г/л, разница с контролем составила 66,6. Применение препарата Д6 в концентрации 0,006 показало наилучшие результаты в сорто-подвойных комбинациях Пинк Леди/ ММ 106 и Пинк Леди/ ПБ 9, разница с контролем составила 69 и 60 соответственно.

Заключение и доступность: Для увеличения количества вегетативных разветвлений и генеративных почек рекомендуется применять регулятор роста Д-6 в концентрации 0,004 г/л.

\section{Список литературы}

1. Барабаш И.П. Фитогормоны. Регуляторы роста (классификация, теория, практика). Ставрополь, 2009.

2. Барабаш И.П. Фитогормоны (эндогенные регуляторы) растении. Садоводство и виноградарство. 2008. № 4. C. $22-23$.

3. Чернов А. И. Способы формирования крон у однолетних саженцев. Научный журнал КубГАУ. 2014. № 98. URL: https://cyberleninka.ru/article/n/sposoby-formirovaniya-kron-u-odnoletnih-sazhentsev. 